Arturs Kucs, Dr. iur, Associate Professor

University of Latvia, Latvia

\title{
IMPORTANCE OF LEGISLATIVE PROCESS IN EVALUATION OF HUMAN RIGHTS LIMITATIONS IN CASE LAW OF THE EUROPEAN COURT OF HUMAN RIGHTS AND THE CONSTITUTIONAL COURT OF LATVIA
}

\begin{abstract}
Summary
Traditionally, the debate about limitations of human rights concentrates on the necessity and proportionality of the proposed legal norms. This article focuses on the criterion which are less debated in evaluation of legal norm limiting human rights, namely, whether the limitation is "prescribed by law". It does not address such aspects of this criterion as accessibility and clarity of legal norm. Instead, it is discussed whether the legislative process and quality of legal norms adopted are among the factors examined by the Latvian Constitutional Court and the European Court of Human Rights when assessing the justification of a restriction of human rights.
\end{abstract}

Keywords: legislative process, restriction of human rights, European Court of Human Rights, Constitutional Court

\section{Introduction}

The article aims to answer the following questions: Does the legislative process of adopting the law limiting fundamental rights have any impact on the evaluation of legality of such limitations? Can the Parliament in urgency procedure without discussions pass a law which severely restricts fundamental rights? Is the Parliament restricted in its legislative process only by its own rules of procedure or also by the Constitution and principles of law? If yes, does the Constitutional Court have a competence to check the compliance of Parliament with these rules in legislative process and would not such rights contravene sovereign powers of Parliament and right of Parliament to adopt political decisions? Does the ECtHR examine legislative process when assessing the limitation on human rights? In which cases and under which element of limitation test?

These questions will be assessed first on the basis of analysis of the jurisprudence of the Constitutional Court of the Republic of Latvia. Secondly, the role of the legislative process in the case law of the European Court of Human rights will be analysed. 


\section{Jurisprudence of the Constitutional Court of the Republic of Latvia}

In recent years, the evaluation of the legislative process leading to limitation of human rights is of an increasing importance in the jurisprudence of the Constitutional Court when assessing whether the restriction of human rights is prescribed by law. Furthermore, the Court has also considered this criterion when analysing the necessity and proportionality of the restriction. Certain aspects of such approach have also been discussed by the Constitutional Court judges in their dissenting opinions.

\subsection{Was the law adopted in compliance with the procedure established in the legislative framework?}

Already in 2009, the Constitutional Court, when evaluating the legality of some of the austerity measures introduced to overcome the economic crisis, emphasized that:

In a democratic state the process of adopting a law restricting fundamental rights should allow the society to be sure about the lawfulness of the particular legal act. The society should form an impression that a thorough prior consideration of the necessity to limit the fundamental rights was carried out during the adoption of the law. ${ }^{1}$

Despite these observations, until 2017 the Court had never declared the legal norm to be contrary to the Satversme (Constitution of the Republic of Latvia) on the basis of the flaws of parliamentary procedure of adoption of disputed legal norm.

In October 2017, while evaluating the constitutionality of the solidarity tax, the Court acknowledged that the parliament has wide, but not unlimited discretion in legislative process: "The Saeima, in exercising its right to legislate and to set the budget, enjoys discretion insofar as the general principles of law and the norms of the Satversme are not violated." Although the Constitutional Court ultimately ruled that the contested aspect of the solidarity tax was not compatible with the principle of equality enshrined in the Satversme, it emphasized that the Parliament had observed the proper legislative procedure, as the evaluation of the necessity of the law was

1 See, for example, the Judgment of the Constitutional Court of the Republic of Latvia of 26 November 2009 in the case No. 2009-08-01, para. 17.2. Available at: https://www.satv.tiesa.gov.lv/web/viewer. html?file=/wp-content/uploads/2016/02/2009-08-01_Spriedums.pdf\#search=2009-08-01 [last viewed October 30, 2019].

2 Judgment of the Constitutional Court of the Republic of Latvia of 19 October 2017 in the case No. 2016-14-01, para. 25.2. Available at: https://www.satv.tiesa.gov.lv/web/viewer.html?file=/ wp-content/uploads/2016/07/2016-14-01_Spriedums-2.pdf\#search=2016-14-01 [last viewed October 30, 2019]. 
based on the assessment of large amount of data and all the stakeholders were given a chance to express their opinion on the draft legislation. ${ }^{3}$

In a subsequent judgement, the Court made clear that the Parliament must not ignore the principle of good legislation. ${ }^{4}$ When analysing the constitutionality of norms regulating the relationship of compulsory lease ${ }^{5}$, the Constitutional Court introduced detailed criteria that should be used in assessing whether the Parliament has complied with this principle:

[..] to evaluate whether the disputed norms are adopted in compliance with the procedure established in the legislative framework, the Constitutional Court must determine whether the legislator has sufficiently analysed the compliance of the disputed norm limiting the fundamental rights with the Satversme in the context of the set case law of the Court regarding the forced lease. ${ }^{6}$

It was also noted that the legislator had the duty to analyse the impact of a proposed limitation of fundamental rights before the introduction of the particular norm. The Constitutional Court emphasized that if, in the course of adopting a legal norm, arguments were presented regarding its possible incompatibility with the norms of higher legal force or the case law of the Constitutional Court, the legislator should examine these arguments. ${ }^{7}$ In the case at hand, the Court essentially found that the Saeima had not paid due attention to the objections and proposals of several stakeholders, and did not have at its disposal due analysis and substantiation of the constitutionality of the restriction of land owners' right to property included in the contested norms. ${ }^{8}$ Therefore, the norms, which were aimed

3 See also Dissenting opinion of the Judge of the Constitutional Court of the Republic of Latvia Daiga Rezevska of 2 November 2017 in the case No. 2016-14-01. Available at: https://likumi.lv/ta/ $\mathrm{id} / 295883$ [last viewed October 30, 2019].

4 See more about the principle of good legislation in: Pleps J. The Principle of Good Legislation. Grām.: The Quality of Legal Acts and its Importance in Contemporary Legal Space. Riga: University of Latvia Press, 2012, pp. 16-26. Krūkle G. Likumdošanas un tiesu varas savstarpējā mijiedarbība. Aktīvā un pasīvā tiesnešu tiesību parlamentārā kontrole [Interaction between the legislature and the judiciary. Active and passive parliamentary control of the rights of judges]. In: Latvijas Universitātes Juridiskās fakultātes 7. starptautiskā zinātniskā konference Tiesību zinātnes uzdevumi, nozīme un nākotne tiesību sistēmās I. Konferences rakstu krājums [University of Latvia, Faculty of Law, $7^{\text {th }}$ International Scientific Conference: Tasks, Significance and Future of Legal Science in Legal Systems. Conference Proceedings, Vol. I]. Riga: University of Latvia, 2019, p. 524.

5 Compulsory lease is a maximum lease fixed by Parliament, which the land owners can request from the owners of flats or houses built on their land plots. This complex legal relationship was created in the course of land reform after the end of Soviet occupation, when the nationalized property was returned to the former owners or their successors, while in the meantime public houses had been built on these land plots.

6 Judgment of the Constitutional Court of the Republic of Latvia of 12 April 2018 in the case No. 2017-17-01, para. 21.3. Available at: https://www.satv.tiesa.gov.lv/web/viewer.html?file=/ wp-content/uploads/2017/07/2017-17-01_Spriedums.pdf\#search=2017-17-01 [last viewed October 30, 2019].

Ibid.

8 Pleps J. Satversmes tiesa un labas likumdošanas princips: piezīmes par spriedumu lietā Nr. 2018-11-01 [The Constitutional Court and the principle of good legislation: remarks on the judgment in case No. 2011-01-11-01]. Jurista Värds, No. 12, 2019. 
to decrease the amount of compulsory land lease, were found to be incompatible with the Satversme. However, this decision of the Court was not unanimous. It was emphasized by dissenting judges of the Court that the Parliament enjoyed discretion in establishing the rules of its own procedure and the Court had acted beyond its competence when declaring the disputed norm unconstitutional on the basis of the shortcomings in the legislative procedure. ${ }^{9}$

The idea that in a democratic state governed by the rule of law the legislative procedure leading to restrictions of fundamental rights of an individual should be transparent, well-argued and understandable for the individual was again expressed more recently. In a case that was initiated based on the application submitted by several employees of a number of state-established higher education institutions, the Court ruled that a law, which requires the publication of information about, inter alia, the remuneration of all employees of state-established institutions of higher education, as well as other monetary amounts that they are entitled to, on the Internet homepages of the respective higher education institutions for at least eight years is not compatible with the Constitution of the Republic of Latvia. One of the main arguments the Court used was that the legislator had not observed the proper legislative procedure, which "should not only be in compliance with the formal requirements set in law, but also enhance the trust of the society towards the state and the law." ${ }^{10}$ In particular, the Parliament had not evaluated the objections of the President of the Republic of Latvia as regards the law and had not made sure that the contested legislation is compatible with the EU General Data Protection Regulation, which although not legally binding at the time of the parliamentary procedure, was in force already.

However, the Court apparently narrowed down the principle of good legislation. The Court pointed out that only a serious error of the legislator can be considered as a sufficient reason to declare the law unconstitutional: "Not every shortcoming can be sufficient grounds to declare that the law has no legal effect. In order to declare a legal act null and void because of a procedural deficiency, there must be reasonable doubt that a different decision would have been achieved in the case if the proper procedure would have been observed." ${ }^{11}$ As regards the particular case, it was ruled

9 Dissenting opinion of the Judge of the Constitutional Court of the Republic of Latvia Gunārs Kusinš of 26 April 2018 in the case No. 2017-17-01. Available at: https://www.satv.tiesa.gov.lv/ web/viewer.html?file=/wp-content/uploads/2017/07/2017-17-01_Atseviskas_domas_Kusins. pdf\#search=2017-17-01 [last viewed October 30, 2019]; Dissenting opinion of the Judges of the Constitutional Court of the Republic of Latvia Aldis Lavinš̌ and Jānis Neimanis of 25 April 2018 in the case No. 2017-17-01. Available at: https://www.satv.tiesa.gov.lv/web/viewer. html?file=/wp-content/uploads/2017/07/2017-17-01_Atseviskas_domas_Lavins_Neimanis. pdf\#search=2017-17-01 [last viewed October 30, 2019].

10 Judgment of the Constitutional Court of the Republic of Latvia of 6 March 2019 in the case No. 2018-11-01, para. 18. Available at: https://www.satv.tiesa.gov.lv/web/viewer.html?file=/ wp-content/uploads/2018/07/2018-11-01_Spriedums.pdf\#search=2018\%2011\%2001 [lastviewed October 30, 2019].

11 Judgment of the Constitutional Court of the Republic of Latvia of 6 March 2019 in the case No. 2018-11-01, para. 18.5. Available at: https://www.satv.tiesa.gov.lv/web/viewer.html?file=/ wp-content/uploads/2018/07/2018-11-01_Spriedums.pdf\#search=2018\%2011\%2001 [last viewed October 30, 2019]. 
that the disputed norm was not adopted in accordance with the principle of good legislation. The violations in the case at hand, especially if viewed in their context, according to the Court, had to be considered serious. ${ }^{12}$ The Court had reasonable doubt that, if the Parliament would have taken into account the objections of the President of the Republic of Latvia, as well as those expressed by the Ministry of Justice, the Legal Department of Saeima, the Data State Inspectorate and other stakeholders, the legislative procedure would have allowed the Parliament to come to a different conclusion, comparing to the one enshrined in the contested regulation. ${ }^{13}$

\subsection{Was the law necessary in a democratic society?}

The Constitutional Court has also analysed the legislative process under the necessity requirement of limitations on human rights. In assessing the constitutionality of the norm of Education Law, which imposed absolute and lifelong prohibition for a person, who has been convicted for serious or particularly serious crime, to work as a teacher, the Constitutional Court expressis verbis referred to the findings of the European Court of Human Rights:

It follows from the judicature of the European Court of Human Rights that in assessing the proportionality of an absolute prohibition it should be examined, whether the legislator has:

1) substantiated the need for an absolute prohibition;

2) assessed its essence and the consequences of application thereof;

3) substantiated that if an exception to this absolute prohibition were envisaged the legitimate aim of the restriction on fundamental rights would not be reached in equal quality. ${ }^{14}$

From these findings of the ECtHR, the Constitutional Court of Latvia also drew its duty to ascertain, whether the legislator had:

1) substantiated the need for an absolute prohibition;

2) assessed its essence and the consequences of application thereof;

3) substantiated that if an exception to this absolute prohibition were envisaged the legitimate aim of the restriction on fundamental rights would not be reached in equal quality. ${ }^{15}$

12 Ibid.

13 Ibid.

14 Compare ECHR judgment of 22 April 2013 in case Animal Defenders International v. United Kingdom (application No. 48876/08), para. 108.

15 Judgment of the Constitutional Court of the Republic of Latvia of 24 November 2017 in the case No. 2017-07-01, para. 19. Available at: https://www.satv.tiesa.gov.lv/web/viewer.html?file=/ wp-content/uploads/2017/03/2017-07-01_Spriedums.pdf\#search=2017\%2007\%2001 [lastviewed October 30, 2019]. 
Applying these criteria to the particular case, the Court noted that the drafting materials of the contested norm did not provide a confirmation that the legislator had examined, whether, indeed, in all cases the lifelong prohibition for someone who had been recognized as guilty of committing a serious or a particularly serious crime to work as a teacher was substantiated. Likewise, the Constitutional Court did not establish that, following the adoption of the contested norm, the legislator had re-examined the need to retain the absolute prohibition. ${ }^{16}$ The Court was also not convinced that the Parliament in setting the absolute prohibition to work as a teacher, had discussed it on its merits and had substantiated the need for an absolute prohibition. ${ }^{17}$

\section{Case law of the European Court of Human Rights}

Before looking at the case law of the ECtHR, it must be noted that because of its supra-national nature, competencies of the ECtHR differ from the competencies of any national courts, including constitutional courts. The ECtHR has traditionally emphasized that margin of appreciation must, inevitably, be left to the national authorities, who by reason of their direct and continuous contact with the vital forces of their countries are, in principle, better placed than an international court to evaluate local needs and conditions. ${ }^{18}$ These differences in roles of the courts must also be borne in mind when comparing the findings of the ECtHR and the Constitutional Court of the Republic of Latvia, especially as regards the principle of good legislation as the legislative procedure in general of national regulation.

Nonetheless, the European Court of Human Rights has, in a number of cases, assessed the legislative process and considerations of the legislature to determine whether a restriction of human rights was necessary, and whether a fair balance had been struck between the competing interests in each particular case.

In 2003, in deciding whether the United Kingdom had struck a fair balance between the economic interests of the state and the right of applicants to private life that was disturbed by the noise of the nearby airport, the ECtHR outlined that a governmental decision-making process concerning complex issues of environmental and economic policy such as in the present case must necessarily involve appropriate investigations and studies in order to allow them to strike a fair balance between the various conflicting interests at stake. ${ }^{19}$ Among other things,

16 Judgment of the Constitutional Court of the Republic of Latvia of 24 November 2017 in the case No. 2017-07-01, paras 19.1, 19.2.1. Available at: https://www.satv.tiesa.gov.lv/web/viewer. html?file=/wp-content/uploads/2017/03/2017-07-01_Spriedums.pdf\#search=2017\%2007\%2001 [last viewed October 30, 2019].

17 Ibid., para. 19.2.2.

18 ECHR judgment of 21 June 2006 in case Maurice v. France (application No. 11810/03), para. 117.

19 ECHR judgment of 8 July 2003 in case Hatton and others v. United Kingdom (application No. 36022/97), para. 128 . 
as the government had consistently monitored the situation and the legislation in place had been preceded by a series of investigations and studies, the Court found no violation of the rights of the applicants.

Similar line of argumentation was followed in case Evans v. United Kingdom regarding the necessity for the father's consent to the continued storage and implantation of fertilised eggs. The Grand Chamber agreed with the previous judgment of the Chamber that it is relevant that the law, which limited the right to private and family life, was the culmination of an exceptionally detailed examination of the social, ethical and legal implications of developments in the field of human fertilisation and embryology, and the fruit of much reflection, consultation and debate. $^{20}$

However, it is not the case that the legislative procedure in the United Kingdom had always pleased the ECtHR. In Dickson v. United Kingdom, the Court ruled that the refusal to grant artificial insemination facilities to enable a serving prisoner to father a child was a violation of the applicants' right of private life. The Court found no evidence that, when fixing a policy for these kinds of situations, the Secretary of State had sought to weigh the relevant competing individual and public interests or assess the proportionality of the restriction. Moreover, since the policy was not embodied in primary legislation, the various competing interests were never weighed, nor had issues of proportionality ever been assessed by Parliament. ${ }^{21}$

Thus, it can be argued that the ECtHR in determining whether a fair balance has been struck between competing interests may, inter alia, assess the quality of the legislative procedure. It pays attention to whether the national legislator has done its due research and has weighed all the competing interests in assessing the proportionality of the limitation. Constitutional Court of the Republic of Latvia does that as well, but it attributes this duty to the quality of law rather than the proportionality strictu senso.

As regards the limitation of general measures, the ECtHR has noted that a State can, consistently with the Convention, adopt general measures which apply to predefined situations regardless of the individual facts of each case, even if this might result in individual hard cases. ${ }^{22}$ It was the case of the Animal Defenders International v. United Kingdom, that was also quoted by the Constitutional Court of the Republic of Latvia, where the ECtHR ruled that the principle of subsidiarity, the quality of the parliamentary and judicial review of the necessity of the measure, including to the operation of the relevant margin of appreciation, is of particular importance in determining whether general measure is proportional. ${ }^{23}$ In that judgment, the Court

20 ECHR judgment of 10 April 2007 in case Evans v. United Kingdom (application No. 6339/05), para. 86.

21 ECHR judgment of 4 December 2007 in case Dickson v. United Kingdom (application No. 44362/04), para. 83.

22 ECHR judgment of 22 April 2013 in case Animal Defenders International v. United Kingdom (application No. 48876/08), para. 106.

23 Ibid. 
found a refusal of permission for non-governmental organisation to place television advert owing to statutory prohibition of political advertising not to be violating the freedom of expression. It established that the government had been carrying out pertinent reviews of the complex regulatory regime governing political broadcasting in the United Kingdom that came to conclusion that the general measure was necessary to prevent the distortion of crucial public interest debates and, thereby, undermining of the democratic process. ${ }^{24}$

It should be emphasized that each particular situation is analysed by the ECtHR taking into account all the circumstances of the case. The margin of appreciation afforded to the state varies according to the nature of the Convention rights in issue, its importance for the individual and the nature of the activities restricted, as well as the nature of the aim pursued by the restrictions. ${ }^{25}$ The procedural safeguards available to the individual will be especially material in determining whether the respondent State has, when fixing the regulatory framework, remained within its margin of appreciation. ${ }^{26}$

\section{Conclusions}

The Parliament has wide but not unlimited power as regards legislative process, when it decides on limitations of fundamental rights. It is the duty of constitutional courts to examine whether the Parliament has acted in accordance with the principle of good legislation when adopting laws limiting fundamental rights. The aim of this examination is not to challenge the sovereign powers of Parliament or to substantiate the Parliament's decision by its own, but to enhance the trust of society in legislator and to ensure that decision-making process was fair, had duly respected the interests safeguarded for the individual and struck a fair balance between the various conflicting interests. There are differences among ECtHR and Latvian Constitutional Court when examining the legislative process, which are explained by the different powers and competencies of both courts. However, both courts have not abstained to examine the legislative process and considerations of the legislature when assessing the restrictions of human rights.

\section{BIBLIOGRAPHY}

\section{Literature}

1. Krūkle G. Likumdošanas un tiesu varas savstarpējā mijiedarbība. Aktīvā un pasīvā tiesnešu tiesību parlamentārā kontrole [Interaction between the legislature and the judiciary. Active and passive parliamentary control of the rights of judges]. In: Latvijas Universitātes Juridiskās fakultātes 7. starptautiskā zinātniskā konference Tiesību zinātnes uzdevumi, nozīme un

${ }^{24}$ ECHR judgment of 22 April 2013 in case Animal Defenders International v. United Kingdom (application No. 48876/08), para. 106.

25 ECHR judgment of 23 March 2017 in case A.-M.V. v. Finland (application No. 53251/13), para. 83.

26 Ibid., para. 84. 
nākotne tiesību sistēmās I. Konferences rakstu krājums [University of Latvia, Faculty of Law, $7^{\text {th }}$ International Scientific Conference: Tasks, Significance and Future of Legal Science in Legal Systems. Conference Proceedings, Volume I] Riga: University of Latvia, 2019.

2. Pleps J. Satversmes tiesa un labas likumdošanas princips: piezīmes par spriedumu lietā Nr. 2018-11-01 [The Constitutional Court and the principle of good legislation: remarks on the judgment in case No. 2011-01-11-01]. Jurista Värds, No. 12, 2019.

3. Pleps J. The Principle of Good Legislation. Grām.: The Quality of Legal Acts and its Importance in Contemporary Legal Space. Riga: University of Latvia Press, 2012.

\section{Legal practice}

1. ECHR judgment of 8 July 2003 in case Hatton and others v. United Kingdom (application No. 36022/97).

2. ECHR judgment of 21 June 2006 in case Maurice v. France (application No. 11810/03).

3. ECHR judgment of 10 April 2007 in case Evans v. United Kingdom (application No. 6339/05).

4. ECHR judgment of 4 December 2007 in case Dickson v. United Kingdom (application No. 44362/04).

5. ECHR judgment of 22 April 2013 in case Animal Defenders International v. United Kingdom (application No. 48876/08).

6. ECHR judgment of 23 March 2017 in case A.-M.V. v. Finland (application No. 53251/13).

7. Judgment of the Constitutional Court of the Republic of Latvia of 26 November 2009 in the case No. 2009-08-01. Available at: https://www.satv.tiesa.gov.lv/web/viewer.html?file=/ wp-content/uploads/2016/02/2009-08-01_Spriedums.pdf\#search=2009-08-01 [last viewed October 30, 2019].

8. Judgment of the Constitutional Court of the Republic of Latvia of 19 October 2017 in the case No. 2016-14-01. Available at: https://www.satv.tiesa.gov.lv/web/viewer.html?file=/ wp-content/uploads/2016/07/2016-14-01_Spriedums-2.pdf\#search=2016-14-01 [last viewed October 30, 2019].

9. Judgment of the Constitutional Court of the Republic of Latvia of 24 November 2017 in the case No. 2017-07-01. Available at: https://www.satv.tiesa.gov.lv/web/viewer.html?file=/ wp-content/uploads/2017/03/2017-07-01_Spriedums.pdf\#search=2017\%2007\%2001 [last viewed October 30, 2019].

10. Judgment of the Constitutional Court of the Republic of Latvia of 12 April 2018 in the case No. 2017-17-01. Available at: https://www.satv.tiesa.gov.lv/web/viewer.html?file=/wpcontent/uploads/2017/07/2017-17-01_Spriedums.pdf\#search=2017-17-01 [last viewed October 30, 2019].

11. Judgment of the Constitutional Court of the Republic of Latvia of 6 March 2019 in the case No. 2018-11-01, para. 18. Available at: https://www.satv.tiesa.gov.lv/web/viewer.html?file=/ wp-content/uploads/2018/07/2018-11-01_Spriedums.pdf\#search=2018\%2011\%2001 [last viewed October 30, 2019].

12. Dissenting opinion of the Judge of the Constitutional Court of the Republic of Latvia Gunārs Kusiņs of 26 April 2018 in the case No. 2017-17-01. Available at: https://www.satv.tiesa.gov. lv/web/viewer.html?file=/wp-content/uploads/2017/07/2017-17-01_Atseviskas_domas_ Kusins.pdf\#search=2017-17-01 [last viewed October 30, 2019].

13. Dissenting opinion of the Judges of the Constitutional Court of the Republic of Latvia Aldis Laviņš and Jānis Neimanis of 25 April 2018 in the case No. 2017-17-01. Available at: https:// 

and National Legal Systems: International Public and Human rights

www.satv.tiesa.gov.lv/web/viewer.html?file=/wp-content/uploads/2017/07/2017-17-01 Atseviskas_domas_Lavins_Neimanis.pdf\#search=2017-17-01 [last viewed October 30, 2019].

14. Dissenting opinion of the Judge of the Constitutional Court of the Republic of Latvia Daiga Rezevska of 2 November 2017 in the case No. 2016-14-01. Available at: https://likumi.lv/ta/ id/295883 [last viewed October 30, 2019].

\section{Other sources}

1. Latvijas Valsts Prezidenta 2019. gada 17. aprịḷa vēstule Saeimas Priekšsēēetājai Inārai Mürniecei [Letter of the President of the Republic of Latvia of 17 April 2019 to the Speaker of the Saeima Ināra Mürniece]. Available at: https://www.president.lv/storage/kcfinder/files/ citi/likumdo\%C5\%A1ana/Darba_lik_groz_virsstundas-VP_vestule_Saeimai-17.04.2019.pdf [last viewed October 30, 2019]. 